\title{
Gender Caring: The Everyday Construction of Black African Parents in Finland
}

\author{
MATHIAS E. EBOT \\ Department of Social Sciences, University of Eastern Finland, Joensuu
}

\begin{abstract}
The Nordic countries are now firmly ensconced in academia as gender-friendly welfare states. They are seen as pioneering countries with respect to changes in family life and gender relations and thus present an interesting forum for family research. This paper explores how gender caring relates to gender, religion and parenting in SubSaharan African families in the context of immigration to Finland. A constructionist perspective is employed to illuminate how guidelines or scripts established in these parents' cultures are actively used and how they in turn influence their gender relations. Gender caring is conceptualized as an ethic of reciprocity, solidarity and obligation to ensure interdependence and strong bonds among black African parents. The article draws on in-depth interviews conducted with twelve couples mainly in the Helsinki area (which includes Helsinki, Espoo, Vantaa and Kauniainen).
\end{abstract}

Keywords: Black African Parents, Sub-Saharan Africans, Religion, Gender Caring, Finland.

\section{Introduction}

The Nordic countries including Finland are pioneers of change in gender relations and family life. They praise themselves on their 'women-friendly' welfare states and being world champions in their achievements in gender equality (Keskinen 2012; Magnusson et al. 2008; Mulinari et al. 2009). National- and cultural branding is combined to harbour a vision of equal, emancipated and liberated citizens. Family policies are focused on realizing the 'dual-earner/dual-caregiver' family model, which is seen as helping to establish a firm economic foundation for families, women's economic independence, and better relations between fathers and children (Haas \& Hwang in Shwalb et al. 2013).

By so doing, current paradigms for studying family relations often direct our attention away from the large-scale social dynamics and reality. One notable field is in parenthood and parenting, where the ideology of gender equality and shared parenting is accepted as the prevalent social norm (Lammi-Taskula 2008; Perälä-Littunen 2007; Vuori 2001). The main concepts in this field come from the global North (i.e. Nordic 
Region, North America and Western Europe), and reflect the social experiences and intellectual politics of the metropolis. Would perspectives of family life from parents coming from the South, whose voices are seldom heard, make any difference?

In moving to Finland, the black African parents in this study faced unequivocal challenges. They are the most hated (Kaartinen 2004 in Lehtomäki 2005) and most disrespected group in Finland. Finnish attitudes toward immigrants can be seen and stereotypical discourses used are well documented in recent literature (Heikkilä 2005; Jaakkola 2009; Puuronen 2011; Rastas 2009). Often, their orientation towards family life, including for instance bigger family size than is typical in Finland, is both questioned and rejected. Black African parents constitute the highest group from Africa living permanently in Finland (Finnish Immigration Service 2011). They have often lost the social structures that supported their parenting values, beliefs and strategies (see Ochocka \& Janzen 2008). Earlier research has considered the impact of parental social support networks and socio-economic status (Marshall et al. 2001; Sundar \& Ochocka 2005) on parenting practices. Black African parents in Finland face additional stresses associated with the experience of separation by distance to family members, Finnish language proficiency, changes in family roles and different cultural expectation about behaviour (Gonslaves 1992; Lamberg 1996), diminished occupational status, a tough climate, having a black skin colour, and prejudice. The Finnish service provider may often judge them as patriarchal families, those who will do parenting in a peculiar way, possibly due to the lack of sufficient knowledge of the cultural and social background of black African parents.

This paper conceptualizes gender caring as an ethic of reciprocity, solidarity and obligation to ensure interdependence and strong bonds among black African parents. For these parents, loyalty, mutual support, and provision of care is primarily culturally and religiously valued, even though there are pragmatic difficulties to cope with regarding limited resources in the context of immigration and acculturation (Fon 2009; 1997; Hafford 2003). Black African parents in Finland provide an orientating framework for understanding the link between gender, religion and parenting. The position of these families to act as a bridge between black African immigrants and the host society is most prominent in the constructionist framework. It is therefore not accidental that their everyday constructions produced in this analysis are articulated around a number of themes - such as paid employment, home life and religious life. These themes reveal not only cultural notions of parenthood among black African parents but also some trends regarding their integration processes in Finland. For instance, it is less apparent in the Finnish literature the extent to which religion regulates and inspires parenting practices and the degree to which black African parents feel compelled to achieve parenting success as a faith-based imperative (Husain 2013). My main aim is thus to demonstrate the relation between gender and religion in black African families, to map out these parents' descriptions of gender relations and parental responsibilities 
in their households, as well as the basis of these characterizations in the context of Finland. My second aim is to attract the attention of Finnish family authorities - not only to the fast-growing population of black African families but also to the currency religion has gained in their lives- religion is one of the most important influences (see also Hardy et al. 2011; Husain 2013; Miller \& Thoresen 2003).

The article is part of the bigger research project "Mixed Parenting between native Finns and Sub-Saharan Africans" in Finland. Empirical data for this project represent ten countries of the Sub-Saharan Africa and were collected from May 2010 to May 2013 in Joensuu, Turku, Tampere, Kotka and Helsinki metropolitan area . The present article draws on the first round of data collected, namely in-depth interviews conducted with twelve couples mainly in the Helsinki metropolitan area. It concentrates on the following questions: How do black African parents describe their everyday life at home and work? What is their understanding of gender relations in the context of parenting? What is the role of religion in their lives?

Research on immigration in Finland has mostly categorized immigrants as one group regardless of their background e.g. from North America, Latin America, Asia, Australia and Europe. Concerning Africans, the focus tends to be on Somalis, probably because they were the first large group of African refugees to settle in the country (Degni, Pöntinen \& Mölsä 2006). However, variation of immigrants' countries of origin, numbers, status, years of residence, and even public policies and attitudes among native Finns suggest that research on immigration/immigrants can not only be studied and understood from the Finnish perspective (see Heikkilä 2005). As a country, Finland has been described as a latecomer in the field of immigrant reception (Valtonen 2001), with limited availability of especially longitudinal data regarding immigration (Salmenhaara 2008). Nevertheless, black African parents are still being assessed against new Nordic family ideals (gender equality, shared parenting, and dual-earner/dual-caregiver).

\section{Ideological conformity}

Let us begin by examining why the Nordic countries are firmly ensconced in academia as gender-friendly welfare states. As a starting point, the social and economic status of women is one sphere where significant changes have occurred over the past decades. This is mainly because women as mothers are financially supported by the state (Perälä-Littunen 2007) and they have high levels of labour force participation, particularly in the public service sector (Kuronen 1999). Nordic countries including Finland have a comprehensive family policy established in the 1970s, designed to provide services for families with children at a relatively generous level. Women's active participation in higher education and the labour market is common-place. Since the 1960s the numbers of Finnish women working outside their homes has increased steadily. The country is known to have had a long tradition of women's full-time em- 
ployment (Haataja 2009; Lammi-Taskula 2008) because by the early 1990s, $75 \%$ of Finnish mothers were working (Kartovaara \& Sauli 2000). It has also been noted in the literature that after the First and Second World Wars, paid labour of women was needed in the reconstruction of the Finnish economy (Lammi-Taskula 2008), thus illuminating why families needed two salaries (Anttonen 1994; Julkunen 1994).

This contributed significantly to the dramatic change in family life and policy. The norm of a male-breadwinner family was replaced and shaped by social and family policies to include dual-earner parents who were both also involved in everyday childcare activities. In this light, Finnish parents have the possibility to take parental and family leaves so they can stay at home and take care of young children while receiving compensation. Policy makers are convinced that children's wellbeing is enhanced by policies that promote children having a secure economic base with two working parents (Haas \& Hwang in Shwalb et al. 2013) and a secure emotional base with two parents who are actively involved in and responsible for their care (Lundqvist 2011; 2012).

Thus, shared parenting became the norm. It is now notably the dominant parenting ideal in the Nordic countries, introduced as a way of increasing gender equality between parents, but later gaining credibility as a way of promoting the reciprocal developments between father and child (Kugelberg 1999). In the Finnish context, good parenting is said to be realized in the form of shared parenting (Nätkin 1997 in Perälä-Littunen 2007), and the country is officially committed to the ideology of gender equality (Perälä-Littunen 2007). Family policies incorporate gender equality and this is reflected in how child care and family leaves are arranged (Kurtz 1997; Phoenix \& Woollett 1991).

The burgeoning multidisciplinary of Finnish literature points out gender equality efforts in parenting, gendered use of parental leave, and the 'dual-earner/dual-caregiver' family model. However, studies have overlooked the link between gender equality and spirituality in the context of family life. In other words, the official rhetoric of gender quality becomes detached from religion. Gender differences and different religious responsibilities for men and women become ignored and hidden. Religion is formally supposed to play a role, when men and women in heterosexual families 'do gender'. Thus, the circumstances of doing fatherhood and motherhood are characterized by place and time (Lammi-Taskula 2008), according to the specific family involved, which also includes religious, economic, and political influences (Connell 1995). However, the clash between religious values and Nordic gender equity ideology is typically overlooked.

Scholarships on parenthood in Finland have not incorporated black African parents. Also, the researchers are mostly native Finns and scrutiny has primarily been limited to middle-class white heterosexual native Finnish couples. This may be a limitation in the situation where policy goals also aim at guaranteeing population growth to replace the ageing population or stabilizing fertility levels (Buchanan \& Rotkirch 2013) or 
combating divorce, a social problem (Koskela 2012) in most Western European countries (Coleman 2013). What is more, 46 percent of women were childless at age 30 , and among men the corresponding figure was 61 percent in 2008 (Statistics Finland 2010a). While some of the divorcées/divorcés/childless young adults may (re)marry and have children later, lifetime childlessness is expected to increase all over Europe in the future (Frejka \& Sardon 2006; Sobotka 2009). In the most recent comparative study of women's postponement of parenthood in three Baltic Sea areas (St Petersburg, Estonia and Finland), Finland was revealed to have the highest proportion of childless women with no child bearing plans (Regushevskaya et al. 2013). Limiting research to parenting in these regions has obviously yielded important insights, and their experience and utility is widely recognized. However, native Finnish parents cannot deny that pluralism, urbanization, and immigration have made them rub elbows with black African parents who hold different beliefs and lifestyles. Education and schooling in contemporary Finland are viewed both as pillars of cultural sustainability and producers of new culture, with knowledge being the key. It is thus impossible to set goals for education and schooling without knowledge of culture and cultural differences.

\section{Construction in black African families}

A theory of gender structure in families should pay attention not only to race and religion but also to how these structures shape individual choice and social interaction and how human agency creates, sustains, and modifies current structures (Risman 2004: 433). Therefore, family ideals implemented in the Nordic space, and more broadly, the sociological concepts commonly used in the West to expound family life are of limited use in satisfactorily explaining the processes occurring in black African families. Notably, the application of notions such as gender roles, agency, and equality may clash with the understanding of these words against the backdrop of Africans' cultures and religions, and thus restrict the individuals' options to follow their own beliefs and ideals. In these families, gender remains a fundamental difference shaping and regulating the organizations of this institutional domain (Conell 2002; Glenn 2000; Risman 2004).

Black African parents draw on their cultural and religious background as well as those in the host country. They function in and adjust to the host society with informed cultural meanings; associated social practices and interact culturally, with multiple influences on the host society (Foner 1997). This explains why they have been found to rely on pre-migration frameworks and practices as 'coping strategies' in a bid to mediate multiple stressors whilst easing their settlement (Foner 2009; Levitt 2001). Gendered caring in this regard appears to be one of many strategies employed by black African parents to navigate discrimination and humiliation in their everyday lives in the host societies. Their children are more likely to be singled-out in schools, have poorer health outcomes than native children, and black African parents experience higher levels of economic hardship (Capps et. al. 2004; Shields \& Berhman 2004). 
In a context such as Finland, a constructionist perspective on black African parents not only uncovers the complex dynamics related to gender and religion but also brings to the fore the production of gendered selves, cultural expectations regarding the performance of 'proper' gender identities, shaping the everyday interactions and structure of their households (see Budgeon 2014). Within this perspective, the importance of active meaning-making is identified, crediting the parents as agents working with each other to understand their worlds. As a set of meanings, the self and its relationship to role performances are understood subjectively through language (Elvin-Nowak \& Thomsson 2001) in cultural and historical contexts (Gergen 1985; 1999a). This language in turn reproduces social organizations. For the black African parents, meanings are based on a 'shared history, perspective, and interpretation of events' (Klein and White 1996: 107).

They are, in turn, embedded in larger sets of social and cultural meanings and ideologies. Though ideologies are actively shaped through language and communication, some become more dominant, enduring to support (Pederson 2012) and become interwoven with other social structures and being taken as the 'truth' (Elvin-Nowak \& Thomsson 2001). Thus, dominant ideologies through their availability as standards against which individual behaviour can be constructed and measured (Woollett \& Phoenix 1991) are used by black African parents to shape and describe behavioural preferences and choices.

\section{Aim, methods and data}

Qualitative data for this study come from in-depth interviews with black African couples, collected alongside data of a broader study concerning mixed parenting in Finland. The objectives are to demonstrate the relation between gender and religion in black African families, to outline these parents' descriptions of gender relations and parental responsibilities in their households as well as the basis of these characterizations in the context of Finland. The analysis draws from twelve in-depth interviews conducted with heterosexual couples mainly in the Helsinki metropolitan area. The interviews were built on a structured protocol which included open-ended questions on the importance of religion to parents, whether equality has a place in their lives, division of labour i.e. how they determined household and family responsibilities, decision making (who does what), whether parents thought their relationship was fair, and how they communicated and attended to each other. Interviews lasted between one to three hours; all were tape-recorded and then transcribed.

Selection of participants was based on the notion of theoretical sampling of Strauss and Corbin (1998), which means selecting and including participants with best knowledge to address the research questions (Cowdery \& Knudson-Martin 2005). The sample purposefully selected parents who have lived permanently in the country for at least 
three years, with young children under six years of age, who were born in Finland (Ebot forthcoming), and for whom care-giving expectations is high (Pederson 2012). Parents were contacted directly by phone and their consent secured. The interviews took place in the participants' homes, chosen by them. All couples were married and residing together with their children; except for two who said they were engaged at the time of the interviews. Mothers and fathers ranged in age from 25 to 38 years. All were raised in Christian traditions and have retained their religious affiliations. Among mothers, six worked full-time, two worked part time and four were not working, while all fathers were working. They work as cleaners, cooks, dishwashers, bus drivers, nurses (taking care of elderly people) and post-delivery men (newspaper delivery at night). African couples in the study were represented by four Cameroonians, four Nigerians, two Ghanaians and two Tanzanians couples. Educational attainment was relatively high: all participants had a university degree, diploma or certificate in some sort of training, indicating they had all completed high school. Those who reported studying were working and studying concurrently (Ebot - forthcoming).

\section{Analysis}

Thematic analysis of the qualitative data was undertaken according to the steps outlined by Braun and Clarke (2006), which states simply that qualitative data be transcribed and independently coded into potential semantic themes related to the research questions. The themes were then reviewed and specifics of each theme refined. As such the analytical categories were not predetermined in grounded theory. Thus, open coding followed by axial coding (Strauss and Corbin 1998) was implemented, while at the same time grouping labels and identifying categories among them. Finally, selection of the excerpts for this analysis was not only according to their exemplar values of sense-making during the interviews but also their pertinence regarding the research interest i.e. around the themes of paid employment, home life and religious life.

\section{Is this Africa or Finland?}

Black African parents, who reported their profession as nurses in this study, work as domestic servants instead - a profession they refer to as shitology. Most of them after graduating and obtaining a degree in nursing at Finnish universities of applied sciences do not work in the hospital but in old peoples' homes. They are responsible when necessary for feeding, supervising the in-takes of medications (prescription drugs) by the elderly but mainly bathing them and making sure they stay clean from urine and excreta. They do not get it easy from the elderly, as this mother describes a situation with an elderly Finnish man at her work:

Mother 4: In my job racism is apparent every day, from the patients mostly but I try not to think about this. During one of my night shifts I was the nurse responsible for that shift and there were practical nurses working. This patient had had a bad day 
I suppose, so he kept calling and calling. This was because the person taking care of him was black, during the morning and afternoon shifts he had still black nurses taking care of him. Then I came at night in charge and I was still black. The man was like where the hell am I - is this Africa or am I living in Finland, get me a Finnish nurse now!!. I told him, I'm sorry - that I'm the person in charge here and if there is anything I will have to take care of it. Also, that he will only have to wait until a Finnish nurse comes in the morning but at this point there is none.

What did he say? He said yes I will wait but refused to eat and to take his medications.

This man apparently denied submitting to care, possibly sickened by the fact that only black nurses have taken care of him all day long. In his own words, until a Finnish nurse comes he does not want anything to do with these black nurses because he is not in Africa. He does not understand why he has been seeing only black people all day -a kind of intersection between race, class/power and gender. The African nurses in turn do not understand such display of ungratefulness. They work in these old peoples' homes where public scrutiny of conditions of employment is hard and particularly have to face harassment ranging from verbal abuse to physical attacks (Carter 2003). According to Heikkilä (2005), this represents facets of racism, prejudices, or stereotypes that signify the cultural nature of vulnerability used in justifying power differentials between nationals and immigrants. Notwithstanding, in most African cultures this would be considered an immense discredit, a shame to an entire family that their elderly is being catered for by complete strangers. According to these cultures, it is a moral imperative for the younger generation to provide for their parents. In other words, this man is supposed to be living with his children or family members who can best cater for him at this stage of his life.

On the other hand, changes happening in Finland at the macro-social level are measured by gender relations and family relations. One of the most outstanding examples of these changes is the externalization and objectification of care as a form of paid work (Moreno Mínguez 2012: 278). This idea has been taken up in Finland to enhance interaction between the State, family and market in the process of democratization of citizens' rights, which in turn reduces gender inequalities. But, the problem posed by the elderly population is becoming increasingly important in terms of Finnish society's future and development. During the last 15 years, demographic change has been presented as one of the central challenges for European social policy (Julkunen \& Pärnänen 2005: 20). If we take a look at the Nordic countries for example, the share of the elderly is projected to increase steadily (Malmberg \& Lindh 2000 in Rauhut 2012; Sommestad 2002 in Rauhut 2012), with Finland appearing to be a special case in terms of expected life-time childlessness combined with relatively high fertility desires and a low preference for childlessness (Goldstein et al. 2003; Miettinen \& Rotkirch 2008).

In this study, the black African parents who are working to meet up with the demands of family life though trapped in blue-collar jobs do not belong inside the Finnish 
'colour scheme' regardless of their services, educational qualifications, skills and competences. While grounded in the hopes and aspirations of a better family life, their migration experiences are fraught with vulnerabilities (Heikkilä 2005; see also Falicov 2007; Hafford 2010; Pine \& Drachman 2005, for the American context). In round terms, they are 'vulnerable immigrants' parents in the Finnish labor market. This is not just a physical condition but that which is socially constructed by the nationals of the country in which they find themselves (Heikkilä 2005). Socially inherited characteristics on this scale definitely have on impact on their children (Forsander 2003) and spouses, and would have harmful effects not only for the entire group but also for social equality at large (Alitolppa-Niitamo 2004). What is more, compared to parents in white collar positions, they are usually in no position to take parental leave due to insufficient information or intimidation. For instance, they may believe that the scheme is mainly for the natives, or some may be afraid to take parental leave because of the influence one perhaps loses when absent from the work place (LammiTaskula 2008). Black African parents oftentimes have unstable labour market positions which can be interpreted as over-representation in the segment of the workforce who are the last to be hired and the first to be fired during economic cycles of boom and depression. This confirms Heikkilä's (2005) views on 'mobile vulnerabilities' as well as Pierson's (1999) ideas on migrant labour taken up as a reserve pool of labour in times of heightened economic activity and laid off in periods of economic recession. Nonetheless, they are constantly reminded of the natives' construction of Finnishness to be self-evident whiteness. For example:

Father 1: I'm a delivery agent, I deliver parcels. Most of the Finnish customers receiving the parcels find it hard to understand how a black man will be delivering their parcels. Each time I call them that I'm bringing them a parcel - they usually think I'm a Finn because my Finnish is quite good (even my Finnish colleagues have told me this). But when I arrive to give their parcels, there is a totally different reaction. Sometimes, they say bad words to me like 'neekeri'(nigga).

Only last week after delivering a parcel to one woman she insulted me 'useless nigga, what are you doing in my country? Go back where you came from. (sinä hyödytön neekeri. mitä sinä teet minun maassani? mene takaisin sinne mistä tulit)

Father 3: I work only at night (post deliver man) and I've had so many incidence of violence directed towards me. Finns attacking me physically and at times they only say things to me like nigga (neekeri).

'Segmentation theory' posits a kind dualism in the labor market which at times involves ethno-stratification of jobs - with certain ethnic groups over-represented in sectors that are avoided by natives. Black African parents are victims and are concentrated in the manual job sectors regardless of their rising level of education in Finland. It is no coincidence that they have been perceived by Finnish employers as more willing to take up manual jobs (Paananen 1999). Participation in paid work is important to 
black African parents because it is often connected to their family needs, not to mention remittances. To compensate for the weak social and economic integration Petts (2009) observes that potentially vulnerable families resort to religion. Employment comprises a means for acquiring income as well as being a major base for the formation of their everyday lives. It is an important activity which acts as a foundation on which parents' systems of meaning and identity are formed.

Mother 3: A parent that has studied and obtained a master's degree certificate in Finland and does not have job that can give him/her 2000 euros monthly but living on a salary of 900 euros like mine - how do you expect that parent to be able to pay for their children's hobbies? The parent does not have the extra money like other Finnish parents.

Father 10: I'm actually living an African life in Finland meaning that I'm the sole provider. They (wife and children) are not in the system; they don't have any kind of support or child money. If my daughter is sick today and I take her to the hospital, bills that people usually pay ten (10) Euros - I will pay about 200 Euros. This is somehow putting a lot of stress on me and deprives me of time to spend with my children/family. In this case to meet up I have to do two/three jobs.

African parents in the current findings overwhelmingly could not imagine themselves without work - let alone the stresses of low paid jobs. This has been supported by earlier research on social class and childrearing experience as key sources of within-culture variation in parenting (Boushel 2000; Cheung \& Nguyen 2001; Harkness \& Super 1996). It is also consistent with Kotchick and Forehand's study that outlined parents' socio-economic status as one of the factors significantly influencing parenting (2002). These parents see themselves struggling to create options which can form a framework of security and help face future and unforeseen difficulties (Lykogianni 2008) for their families. In this regard, work is central to these African parents as it helps to support their vulnerable situations although it would not put them on equal footing with native Finnish parents. They cannot be assessed against new Nordic parenting ideals of dual-earner/dual caregiver family model or shared parenting.

\section{Gender caring}

The black African parents in this study remind us of how the concept of care has been used increasingly as a category of analysis in feminist and social policy research of welfare states. The most common definition involves caring for children, the elderly and those who are ill or disabled. Care according to Bettio and Plantenga (2008), is the activity of looking after people unable to take care of themselves i.e. in health care settings, residual categories of social care (delivered mainly to minors, elderly and the disabled), teaching and special needs education. For black African parents it is an interpersonal practice loaded with emotions that imply relation and interdependence. 
They display it on a daily basis in relation to the gendered rules and behaviours expected between them (Risman 1998). Their everyday life reflects a symbolic gender order which presupposes the family as that of united interest - mutual caring. This assumes the existence of a 'global care chain' (see Hochschild 2002; König \& de Regt 2010), but also underlines a diagnosis we cannot fail to recognize but through its very obviousness, passes without notice. Such a diagnosis does not have to depend on the terms of an indigenous knowledge, though it may certainly draw insight from them (Connell 2007: 96). Father 1: There is no smooth path on this earth but I will say the most important thing that is keeping us together is family communalism i.e. doing things together, communicating with and understanding each other, caring for each other, and very important being there for each other. Family communalism could be easily likened to Schippers' (2007: 91) idea on 'gender relativity' and how it is institutionalized, because the implicit relationship between genders becomes a taken-for-granted feature of interpersonal relationships, culture and social structures. The father herein refers to the commitment of the family unit as husband and wife who love, care and tolerate each other, because they share everything together. It is a position grounded on indigenous knowledge of black African parents, sometimes called local knowledge, and it implies a social diagnosis of their narratives which is rooted in their religious and cultural beliefs, a positive line of thought that is imperative in terms of their economic, social and spiritual development.

The parents emphasized mutual understanding because they have known each other for a long time, having met in their country of origin. It also describes positive moments included in activities performed individually for the spouse, together with the spouse or with the whole family. This reveals how gender caring is implicated in the heterosexual imaginary of black African parents, disguising the extent to which heterosexuality structures family life, including gender relations and thus, privileges heterosexuals while criminalizing homosexuals or lesbians (Ingrham 1996), perhaps in their countries of origin. Nevertheless, a correlation between caring and fertility is very strong for the group (Moreno Mínguez 2012; United Nations Development Programme 2007). Participants also frequently referred to trust, communication, support and caring (e.g. Mother 10: He is actually quite supportive and caring) in their descriptions, while also frequently refraining from verbalizing or elucidating their contents; instead, love and care for the spouse, children and having similar goals were mentioned (e.g. Mother 6: I Love and care about my husband and we have two beautiful kids - we really don't pay attention as to who does what because we have similar objectives. That is, we are heading in the same direction). Elina Schleutker (2014) argues in her study how formal and informal care given to women can impact their decision making (i.e. childrearing or employment) because their heterogeneous preferences transform differently to different lifestyle career strategies. Similarly, Catherine Hakim (2000; 2002) also notes that heterogeneity in women's preferences lead to different choices and is an increasingly important determinant of behaviour especially when it comes to work and family. 
In descriptions categorized as care, participants also highlighted the importance of being close with their in-laws to be a foundation in their relationship (e.g. Father 5: How can you marry someone's daughter and not be close. Those are the people praying for us to survive in this world. One must acknowledge the fact that God is the provider). More so, they described their own and their partner's ways of behaving, feeling or thinking, use of humour, and expressions of affection, such as complimenting the other. (e.g., Father 10: I am always out working and to tell you the truth taking care of two kids, it's more than a full time job. My wife stays at home, she takes care of the house, clean, cook and she has to take care of our kids. She is so supportive). Malinen, Rönkä and Sevón (2010), using a daily relational maintenance perspective to examine positively spousal moments among couples with children found that positive spousal moments often included children, who were described as a landscape for the relationship, as shared responsibility and participants in family life.

\section{Parental responsibilities}

Life in Finland is filled with changes in terms of family structure and gender dynamics for the black African parents. Families studied here are heterosexual and nuclear with mostly two children; only one family had four children. Parents are the ones mainly responsible for the upbringing of their children, since in Finland they do not have their mothers, or other relatives to give them a helping hand with childrearing. For instance, this is what some mothers said: Mother 12: For us foreigners, it is very challenging because we don't have our relatives to look after our kids so that we can have our own 'time together'. Mother 4: I'm working but I don't have a permanent job so most of the time I'm with her at home. I'm a nurse and apart from me and the day-care, I try to involve her father as much as possible. Like today, he was with the child in the morning because I had to go somewhere and I preferred that the child is at home because she has all her toys and it is much more comfortable for her at home.

However, some parents tend to use the services and assistance of friends in childrearing and for those that have family members in Finland their support system is extensive as this mother (3) describes: We are like a big family here in Finland. We keep each other busy and we are like supporting each other. I've two brothers and one sister, my husband also has two brothers - they are also living with their partners and their children so it makes the family very big as we socialize with them and visit each other.

These parents, though first generation of black African parents in Finland are making adjustments. Nancy Foner $(1997 ; 2009)$ looking at immigrant families across generations within the U.S. context found that cultural practices adopted in the country of origin are transferred to the new setting as part of the adjustment process. Black African parents find themselves confronted with hegemonic ideals that are often divergent from those of their countries of origin in Sub-Saharan Africa. Markedly, in terms of family 
structure and composition, their ideals of childrearing and parenting roles do not correspond to those of the host country context. Nonetheless, the gender roles, household relations and responsibilities which structure the process of adaptation in immigrant families have been observed in many other studies (Brunod \& Cook-Darzens 2002; Ochocha \& Janzen 2008; Pels 2000), and in this light the findings in this study add to a growing evidence base.

Mother 1: I teach my daughter how to clean and organize her things. I also cook every day (Cameroonian food) that's why we have never gone to a restaurant and I don't think my daughter will pick up that Finnish habit of going to the restaurant almost on a daily basis because she would grow to see that there is food in the house at all times.

The participants, mostly mothers, acknowledged that they have access to special knowledge about caring for their children. They described their responsibilities and beliefs in terms of their gender i.e. as women they gave birth to their children and thus automatically have a natural connection with their children. They want to do their best for their kids, to teach them good manners, share great moments with them, so that the children feel they are there for them because they intuitively know what their children need.

Mother 12: People usually say to me that I'm a strong woman because I've four children. For me, I know what they need and when they want something, so it's kind of straight forward because they are my children. The most difficult thing for me instead is to see them fighting each other.

The belief that mothers have an innate connection with children especially among black Africans parents is related to the idea that mothers, not fathers, are essential to children's well-being, especially preschool children. Like Perälä-Littunen $(2004 ; 2007)$ found in her studies describing the cultural ideals of a good parent among Finnish informants, and consistent with the ideology of intensive mothering (Hay 1996), the black African mothers in this study identified themselves as the primary caregiver. This is an unsettling circumstance in the context of a gender-friendly welfare state extolled for being world champions in the achievements in gender equality (Keskinen 2012; Magnusson et al. 2008; Mulinari et al., 2009). Black African parents cannot be accessed by these standards because the gender-friendly welfare state policies have not touched their group yet i.e. fathers are usually outside their homes because of the nature of their jobs, they are very busy by being the sole provider.

Mother 8: My husband is the only one working and he has a lot of bills on his head - everything goes to rents and bills. Before, he was paying for our child's daycare fees (about 175 euros) but this stopped after I went to complain to my social worker.

At home, I do all the house chores, I cook, play with children, bath them, and take them to the parks. I don't mind because I know my husband supports me and also helps at times when he is free from work. 
Father 4: The difference between Finnish parents and African parents is that Finnish parents have this rule of dividing the days each parent stays with the child. That is a very foreign idea to us Africans because African mothers only try to engage the father into the child's life as much as possible.

Many mothers organize their time around the children and do not rely on the availability of the fathers. Traditionally, black African mothers assume responsibility for thinking about, managing, and executing child-care tasks. In others words, the responsibility for children falls overwhelmingly on mothers without explicit decisions made (Budlender 2007; United Nations Development Programme 2007). For example, when they organize their time around the children, they assume responsibility that is reflected in a continual focus on their children's needs and what has to be done (Cowdery \& Knudson-Martin 2005). As a result, mothers develop a direct relational connection with their children, proving again that they enjoy and intuitively know what to do for their children. In the United States, mothers remain responsible for primary parenting, assuming emotional responsibility for the caretaking and safety of children (Pedersen 2012), and acting as pivotal figures in family life (Guendouzi 2006). On the other hand, the black African fathers' relationships in the present study were more indirect, developing a kind of task - relationship connection mainly in terms of enforcing discipline and respect.

Mother 4: Of course, I consider my husband the head of our family. I grew up in a culture where the man has to have the final decision that is best for the family after taking into consideration the opinions of his wife and children. I still want this kind of arrangement in our house - not a dictator but someone who would be strict especially when it comes to disciplining the children.

Father 5: My kids have contributed to the fact that I am a good father today because the way I was when I didn't have kids is very different now that I have two children. I take care of my children because my wife is in school. I shower them, play with them, and teach them how to read and how to interact in English. Also, to be family orientated children.

Some fathers in this study saw themselves as responsible for childrearing tasks and spoke of what they are learning. Rather than stepping back from childcare tasks, they sought to learn. Nonetheless, some fathers assume that responsibility is shared only when the mother has an employment outside the home or that she is attending school. This is problematic as the household division of labour remains unbalanced and highly feminized in Finland (see Haataja 2009; Lammi-Taskula 2008; Perälä-Littunen 2007). The imbalances in household division of labour among African families may be one of the key reasons for separation and, thus a significant rise of single African mothers in Finland. Most African mothers as illustrated in figure 1 (Statistics Finland 2013) below, understand the ideology of gender equality is accepted as the norm in the country and will not stand for anything less. 
Figure (1) does not specifically relate to black African families. It includes individuals from all the African countries resident in Finland. The two largest categories namely, Africans married with child/children and single African mothers with child/children, depict a situation where unbalanced household responsibilities without gender caring among African parents may increase the chances of separation and lone parenthood. The figure also suggests that marriage is still a prevailing and respected institution among Africans in Finland. Religion is one good reason for this development and thus concurs with our arguments.

\section{Religion and spirituality}

Overwhelmingly, black African parents in this study assume the position that religion is not only important in their household but it is mainly about a divine being i.e. God. Parents emphasized feelings as the primary source for religious affiliation, and consequently the benefits derived from the Christian faith. It is a kind of an 'eternal truth' that has saved their relationships and in turn would keep their children safe. For them, religious teachings inform about position and status as well as the functions that parents are to fulfill (Husain 2013; Lees \& Horvath 2009). They grew up relating to things they experienced as religious or spiritual from their own parents. In this way, they follow the rational choice theory in positing that religion is always associated with 'supernatural rewards'. As this mother puts it, anyone without religion is lost:

Mother 10: Yes, religion is a good parental practice because based on our experiences it has helped us a lot. In the sense that it's a source of comfort especially in difficult times - even if one doesn't believe in life after death. When you are going through a tough time, you can always comfort yourself with religion - that God has a bigger plan. This is one thing we can always draw from to give us strength to continue with the struggles. It is also a source of hope.

Father 1: I am religious and I know there is a God - this is very vital for me. But in this society where we live religion is not important. Religion has no place; Finnish people (boys and girls, men and women) don't go to church. They have inculcated the Lutheran Christianity by birth but actively they don't go to church. Most of them are against the fact that they are paying 1\% of their salary to the Lutheran Church and nowadays most are resigning from the church. I am telling you if you go to church today you will see only very old people.

The Nordic populations appear on every comparative scale to be among the least believing and least practicing in the world (Bäckström, Edgardh Beckman \& Pettersson 2004, see also the European Values Study). When talking of religion in the Nordic countries, there is a tendency to belong but not to believe. Spirituality per se; is intensely personal, meaning moments of solitude and quiet are necessary. It is more about an individual's quest for meaning and transcendence (Hardy et al. 2011). This might not be actualized only through religion or as a result of meditation because some people find visits to 
a lake/sauna a spiritual experience, others consider tending to their gardening, their paintings, polished furniture, pets and the seaside as places of spiritual exercise (see Noddings 2003). Nonetheless, for the Finnish state, democracy has taken the former space of spirituality (Koski \& Filander 2012). In Finland, people who remain members of the church use their services mainly for baptisms, confirmations and marriages. In this sense, membership could be seen as part of a national identity - probably just as much as a religious identity (Davie in Ammerman 2007).

Mother 4: Most definitely, I am religious and I had baptized my child when she was lyear old. And since, I am her primary care giver, she is going to fellowship in the same church as me because I am a Catholic Christian.

I grew up in a very religious home (God fearing home) and my mom always made me to understand that there is a God somewhere and we just have to trust and believe in him. You know, my faith might not be right at the top of the rocks but I believe there is a God somewhere and it's something I want to implant in my child as well.

Father 5: Religion has taken us to the right path. When you listen to the teachings of the bible, they guide your life i.e. don't fornicate or don't become an alcoholic. So, we think now it's the time for them (Children) to learn because they are young and it would stay with them. You don't wait when they are 15 years old to start teaching these things to them. They won't listen or it would be very difficult.

It is important that attention be given to these black African parents because they selfidentify themselves as religious or spiritual. Throughout the interviews, black African parents refer to their conscious choice of self-identifying religious parents, drawing inspiration and guidance from the monotheistic Christian faith. Besides, many studies in the social science literature have shown the relationship between parenting and inspired religiousness, having positive outcomes in children and adolescents (Hardy et al. 2011; Miller \& Thoresen 2003; Skinner, Johnson \& Snyder 2005).

One sub-theme that emerges here is the reference made to the grace of God as the only possible means of saving their relationship and children.

Mother 1: I think it is only by God's grace that our relationship has lasted for so long i.e. since from Cameroon. It would also be only by the grace of God that these children are going to grow the way we want. Because, this society is influencing a lot i.e. most of the time she is at the daycare, she spends so many hours there from 8am-4pm.

Father 6: I believe in God, my wife believes in God and we want our children to follow that pattern. Children who believe in God would not do certain things because of the fear of the lord - no matter how bad or good the society is. We take our children every Sunday to church, we pray together as family and all of them have been baptized. We understand very well that our children may derail from God when they are adults - that's why we follow up our teachings with prayers so that they grow with these values in them. 
Mother 6: Another thing still on religion and Christianity is that religion controls people i.e. your religion controls you. And because the society is made up of people who control it - whatever they believe in affects the society in which they live. In other words, religion builds and makes society. Take for example, Finnish children who are not religious just like their parents - the result is teenage smoking and alcoholism at the metro stations and bus stops.

It is important to note here that in a preschool context, Lappalainen (2006) argues there is a tendency to represent Finnish society and culture as more secular than it actually is - because Lutheran traditions are embedded in Finnish cultural customs. And some Finns do believe in the existence of God and they do lead a spiritual life. That said, the deeply significant role of family, community and culture in the lives of many Black African parents, is often strengthened by shared experiences in spirituality and religion, which is alien to the mainstream Finnish culture. For example, symbolic religious objects like the bible, rosary beads and the cross are observed by parents, who in turn show these things to their children, accompanied by informal tales of what is good or bad. Black African parents model behaviours such as prayers or reading scripture as a means to adapt to stressful situations (Garland 2002) in the host society. This corresponds to the findings of a qualitative study on Somali parents' experiences of bringing up children in Finland (Degni et al., 2006), in which their parenting practices were shaped by codes in Islam where large family sizes are common, with the father as the household head. Similarly, Altaf Husain (2013: 167) found that one of the most important strengths of faith-inspired parents is contextualizing explanations for their parenting styles, and the disciplinary approach in religious doctrines. This simply substantiates the use of storytelling rooted in scripture by black African parents to orientate their children to the values of their respective religious traditions. Again, reference to a supreme being has hardly emerged in literature as a condition for proper parenting, let alone to defend gender relations.

Father 2: We both believe in God and I can say that the Christian values are very important in parenting because they have kept us and the children safe. If you draw your children close to the lord they would grow up knowing the things that are good or bad, also right from wrong. We are planning to baptize them and they will take it from there.

Mother 2: We take them to the church every Sunday and then pray together every day as a family. This small one (referring to her 1.8 years old daughter) has even started to say Amen, though not very clearly but it can be heard. That is something because as the child grows, these things/values grow in her. 


\section{Concluding remarks}

The overall aim for this paper has been to propose an orientating framework for understanding the link between gender, religion and parenting in black African families in the Finnish context. Gender caring emerges from these parents' characterizations of gender relations, parental responsibilities in their households as well as their labour market situations outside the home. The example of black African parents indicates that approaching parenting through an everyday constructionist perspective contributes to understanding the dynamic process of its constitution. In this process, our attention has not only been drawn to the socio-partial and temporal practices and meanings of fathers and mothers, but also to the significant link between gender and religion. Therefore, gender caring, parental responsibilities and religion are reproduced and reconstituted, together with the reproduction and reconstitution of the everyday of which they are part. The strength of gender caring is embedded in the ethics of reciprocity, solidarity and obligation. Thus, it is not linked to devalued work generally carried out by women/ mothers in families. If we are to link theoretical and empirical works in family research and policy, this kind of conceptual specification is needed.

Black African fathers and mothers who participated in the research draw upon their different cultural systems as well as their religious beliefs, gender and labour market situations, in order to give meaning to their parental relations and responsibilities. Religion associated with patriarchy may negatively affect these black African women's rights. Yet, a lack of attention to the positive aspects of religion among black African mothers denies a deeper understanding of the potential empowerment they may gain from their religion (Ali et. al. 2008; Traversa 2012). Until now, black African families have been marginalized greatly in Finnish scholarship, and henceforth their inclusion should be encouraged in future research. Future research should also examine concretely what Marks (2004) refers to as the 'costs' of religious practices in black African families. They are numerically a highly significant group in Finland, but have been notably absent from the research agenda. As other parents, their parenting is affected by social, cultural and environmental circumstances and is subject to change. It is open, provisional rather than bounded, fixed and static. To use Massey's (2005: 151) language, it is 'an ever-shifting constellation of trajectories'. 


\section{References}

Ali, S., Mahmood, A., Moel, J., Hudson, C. \& Leathers, L. (2008). A qualitative investigation of Muslim and Christian women's views on religion and feminism in their lives. Cultural Diversity and Ethnic Minority Psychology, 14(1), 38-46.

Alitolppa-Niitamo, A. (2004). The Icebreakers. Somali-speaking youth in metropolitan Helsinki with a focus in the context of formal education. Helsinki: The Family Federation of Finland \& the Population Research Institute, D 42.

Ammerman, N. (ed.) (2007). Everyday Religion: observing modern religious lives. New York: Oxford University Press.

Anttonen, A. (1994). Hyvinvointivaltion naisystävälliset kasvot [The women-friendly faces of the welfare state]. In A. Anttonen, L. Henriksson, \& R. Nätkin (eds.), Naisten hyvinvointivaltio, pp. 203-226. Tampere: Vastapaino.

Bettio, F. \& Plantenga, J. (2008). Care regimes and the European employment rate. In Costabile, L., (ed.), Institutions for social wellbeing. Alternative for Europe, pp. 152-175. London: Palgrave Macmillan.

Boushel, M. (2000). Childrearing across cultures. In M. Boushel, M. Fawcett, \& J. Selwyn (eds.), Focus on early childhood: Principles and realities, pp. 65-77. Oxford: Blackwell Science.

Braun, V. \& Clarke, V. (2006). Using thematic analysis in psychology. Qualitative Research in Psychology, 3(2), 77-101.

Brunod, R., \& Cook-Darzens, S. (2002). Men's role and fatherhood in French Caribbean families: A multi-systematic "resource" approach. Clinical Child Psychology and Psychiatry, 7(4), 559-569.

Buchanan, A. \& Rotkirch, A. (eds.) (2013). Fertility rates and population decline. No time for children? London: Palgrave Macmillan.

Budgeon, S. (2014). The dynamics of gender hegemony: femininities, masculinities and social change. Sociology 2014, Vol. 48(2), 317-334.

Budlender, D. (2007). A critical review of selected time use surveys. United Nations Research Institute for Social Development.

Bäckström, A., Edgardh Beckman, N. \& Pettersson, P. (eds.) (2004). Religious change in Northern Europe - the case of Sweden, Stockholm: Verbum.

Capps, R., Fix, M., Ost, J., Reardon-Anderson, J. \& Passel, J. (2004). The health and well-being of young children of immigrants. Washington, DC: The Urban Institute.

Carter, J. (2003). Ethnicity, exclusion and the workplace. New York: Palgrave Macmillan.

Cheung, M. \& Nguyen, S. (2001). Parent-child relationships in Vietnamese American families. In N. Webb (ed.), Culturally diverse parent-child and family relationships, pp. 261-282. New York: Columbia University Press.

Coleman, A. (2013). Partnership in Europe; its variety, trends and dissolution. A section of a work in progress. Finnish Yearbook of Population Research XLVIII 2013, pp. 5-49.

Connell, R. (1995). Masculinities. Cambridge: Polity Press. 2002. Gender. Cambridge: Polity Press. 
2007. Southern theory: the global dynamics of knowledge in social science. Cambridge: Polity Press.

Cowdery, R. S., \& Knudson-Martin, C. (2005). The construction of motherhood: tasks, relational connection, and gender equality. Family Relations, 54 (3), 335-345.

Davie, G. (2007). Vicarious religion: a methodological challenge. In: Ammerman, N. (ed.), Everyday religion: observing modern religious lives, pp. 21-35. New York: Oxford University Press.

Degni, F., Pöntinen, S. \& Mölsä, M. (2006). Somali parents' experiences of bringing up children in Finland: exploring social-cultural change within migrant households. Forum: Qualitative Social Research 7(3): Art. 8 - May 2006.

Ebot, M. E. (Forthcoming). Is education enough? Skilled Sub-Saharan Africans facing Nordic labour market. In: P. Harinen, V. Haverinen \& P. Ahponen (eds.), Dislocations. Aachen/Maastricht: Shaker Publishing Group.

Elvin-Novak, Y. \& Thomsson, H. (2001). Motherhood as idea and practice: a discursive understanding of employed mothers in Sweden. Gender and Society, 15(3), 407-428.

Falicov, C. (2007). Working with transnational immigrants: expanding meanings of family, community, and culture. Family Process, 46(2), 157-171.

Finnish Immigration Service (2011). Foreign citizens living permanently in Finland, $31^{\text {st }}$ of December in 2011. Accessed 10 $0^{\text {th }}$ March, 2012.

Foner, N. (1997). The immigrant family: cultural legacies and cultural changes. International Migration Review, 31(4), 891-904.

2009. Introduction: intergenerational relations in immigrant families. In N. Foner (Ed.), Across Generations: Immigrant families in America, pp. 1-20. New York: New York University Press.

Forsander, A. (2003). Insiders or outsiders within? Immigrants in the Finnish labor market. Population Research Institute, Yearbook of Population Research in Finland 39: 55-72.

Frejka, T., \& Sardon, J-P. (2006). First birth trends in developed countries: persisting parenthood postponement. Demographic Research 15(6): 147-180.

Garland, D. (2002). Faith narratives of congregates and their families. Review of Religious Research, 44(1), 68-92.

Gergen, K. (1985). The social constructionist movement in modern psychology. American Psychologist, 40(3), 266-275. 1999. An Invitation to Social Construction. London: Sage.

Glenn, EN. (2000). The social construction and institutionalization of gender and race: An integrative framework. In: Ferree MM, Lorber J and Hess BB (eds.), Revisioning Gender, (pp. 3-43). New York: Rowman \& Littlefield.

Goldstein, J., Lutz, W. \& Testa, M. R. (2003). The emergence of sub-replacement family size ideals in Europe. Population Research and Policy (22): 479-462.

Gonslaves, C. (1992). Psychological stages of the refugee process: A model for therapeutic interventions. Professional Psychology: Research and Practice, 23(5), $382-389$.

Guendouzi, J. (2006). “The guilt thing:” Balancing domestic and professional roles. Journal of Marriage and Family, 68(4), 901-909. 
Haas, L., \& Hwang, C. P. (2013). Fatherhood and social policy in Scandinavia, In: D. Shwalb, B. Shwalb \& M. Lamb (eds.) (2013), Fathers in cultural context. New York: Routledge.

Haataja, A. (2009). Fathers' use of paternity and parental leave in the Nordic Countries. Online working papers Helsinki 2/2009, No. WP 1-19. The Social Insurance Institution of Finland (Kela), Research Department. (www.kela.fi/research)

Hafford, C. (2003). Between sisters and cousins: child caretaking and the reproduction of familial interdependence across Dominican migrant households. Unpublished doctoral dissertation. Columbia University, New York.

2010. Sibling caretaking in immigrant families: Understanding cultural practices to inform child welfare practice and evaluation. Evaluation and Program Planning 33 (3), 294-302.

Hakim, C. (2000). Work-lifestyle choices in the $21^{\text {st }}$ century: Preference theory. Oxford: Oxford University Press.

2002. Lifestyle preferences as determinants of women's differential labor market careers. Work and Occupations, 29(4): 428-459.

Hardy, S., White, J., Zhang, Z. \& Ruchty, J. (2011). Parenting and the socialization of religiousness and spirituality. Psychology of Religion and Spirituality, 3(3), 217-230.

Harkness, S. \& Super, C. (eds.) (1996). Parents'cultural belief systems: their origins, expressions and consequences. New York: The Guilford Press.

Hays, S. (1996). The cultural contradictions of motherhood. New Haven, CT: Yale University Press.

Heikkilä, E. (2005). Mobile vulnerabilities: perspectives on the vulnerabilities of immigrants in the Finnish labor market. Population, Space and Place 11(6), 485-497.

Hochschild, A. R. (2002). Love and gold. In: B. Ehrenreich and A. R. Hochschild (eds.), Global woman: nannies, maids and sex workers in the new economy, pp. 15-30. New York: Henry Holt and Company.

Husain, A. (2013). An ecosystem-based model for faith-inspired parenting. Journal of Human Behavior in the Social Environment, 23(2), 159-170).

Ingraham, C. (1996). The heterosexual imaginary: feminist sociology and theories of gender. In S. Seidman (ed.), Queer theory/sociology, pp. 168-193. Oxford: Blackwell.

Jaakkola, M. (2009). Maahanmuuttajat suomalaisten näkökulmasta. Asennemuutokset 1987-2007 [Finnish perceptions of immigrants. Changes in attitudes 1987-2007]. City of Helsinki Urban Facts Publications, Research Series 2009:1.

Julkunen, R. (1994). Suomalainen sukupuolimalli - 1960-luku käänteenä [Finnish gender model - 1960s as a turning point]. In A. Anttonen, L. Henriksson, \& R. Nätkin (eds.), Naisten hyvinvointivaltio (pp. 179-201). Tampere: Vastapaino

Julkunen, R. \& Pärnänen, A (2005). Uusi ikäsopimus (Jyväskylä: SoPhi).

Kaartinen, M. (2004). Neekerikammo. Kirjoituksia vieraan pelosta. Turun yliopisto kulttuurihistoria.

Kartovaara, L. \& Sauli, H. (2000). Suomalainen lapsi [The Finnish child]. Väestö 2000 (Vol. 7). Helsinki, Finland: Tilastokeskus [Official Statistics of Finland]. 
Keskinen, S. (2012). Limits to speech? The racialized politics of gendered violence in Denmark and Finland, Journal of Intercultural Studies, 33(3), 261-274.

Klein, D. \& White, J. (1996). Family theories: an introduction. Thousand Oaks, CA: Sage.

Koskela, J. (2012). Avioero suomalaisen miehen kokemana. Ero ja erosta toipuminen prosessina [Divorcing men as a social problem]. Doctoral dissertation (social policy). Publications of the University of Eastern Finland. Dissertations in Social Sciences and Business Studies no 46.

Koski, L. \& Filander, K. (2012). Transforming causal logics in Finnish adult education: historical and moral transitions rewritten. International Journal of Lifelong Education, 32(5), 583-599.

Kotchick, B. \& Forehand, R. (2002). Putting parenting in perspective: a discussion of the contextual factors that shape parenting practices. Journal of Child and family Studies, 11 (3), $255-269$.

Kugelberg, C. (1999). Perceiving motherhood and fatherhood: Swedish working parents with young children. Unpublished doctoral dissertation, Acta Universitatis Upsaliensis. Uppsala studies in cultural anthropology 26, Uppsala, Sweden.

Kuronen, M. (1999). The social organisation of motherhood-Advice giving in maternity and child health care in Scotland and Finland. Doctoral dissertation, University of Stirling, UK.

Kurtz, D. (1997). Doing parenting: mothers, care work, and policy. In T. Arendell (eds.), Contemporary parenting: Challenges and issues, pp. 92-118. Thousand Oaks, CA: Sage.

König, R. S. \& de Regt, M. (2010). Family dynamics in transnational African migration to Europe: an introduction, African and black diaspora: An International Journal, 3(1), 1-15.

Lamberg, L. (1996). Nationwide study of health and coping among immigrant children and families. JAMA, 276 (18), 1455-1456.

Lammi-Taskula, J. (2008). Doing fatherhood: understanding the gendered use of parental leave in Finland. Fathering, 6(2), 133-148.

Lappalainen, S. (2006). Liberal multiculturalism and national pedagogy in Finnish preschool context: inclusion or nation making? Pedagogy, Cultural and Society, 14(1), 99-112.

Lehtomäki, M. (2005). Finnish-African Marriages in Finland in the $21^{\text {st }}$ Century. Marjaana Lehtomäki, Autumn 2005 (GB). A FAST-FIN-1 Finnish Institutions Research Paper. FAST Area Studies Program. Department of Translation Studies, University of Tampere.

Lees, J. \& Horwath, J. (2009). 'Religious parents... just want the best for their kids': Young people's perspectives on the influence of religious beliefs on parenting. Children \& Society, 23(3), 162-175.

Levitt, P. (2001). The transnational villagers. Berkeley: University of California Press. Lundquist, Å. (2011). Family policy paradoxes. Bristol, UK: Policy Press.

Lundquist, A. (2012). The Gender equal father? The (Welfare) politics of masculinity in Sweden, 1960-2010. In: P. McDonald \& E. Jeanes (eds.), Men, wage work and 
family (pp. 34-49). London:. Routledge.

Lykogianni, R. (2008). Tracing multicultural cities from the perspective of women's everyday lives. European Urban and Regional Studies, 15(2), 133-143

Magnusson, E., Rönnblom, M. \& Silius, H. (eds.) (2008). Critical studies on gender equalities. Nordic dislocations, dilemmas and contradictions. Göteborg: Makadam.

Malinen, K., Rönkä,A. \& Sevón, E. (2010). Good moments in parents' spousal relationships: a daily relational maintenance perspective. Family Science, 1(3-4), 230-241.

Malmberg, B. \& Lindh, T. (2000). Fryrtiotalisternas uttåg - Om tjugohundratalets demografiska utmaningar. Stockholm: Fritzes förlag.

Marks, L. (2004). Sacred practices in higher religious families: Christian, Jewish, Mormon, and Muslim perspectives. Family Process, 43(2), 217-231.

Marshall, N., Noonan, A., McCartney, K., Marx, F. \& Keefe, N. (2001). It takes an urban village: parenting networks of urban families. Journal of Family Issues. Special Issue: The household in its neighbourhood and community, 22 (2), 163-182.

Massey, D. (2005). For space. Oxford: Sage.

Miettinen, A. \& Rotkirch, A. (2008). Milloin on lapsen aika? Lastenhankinnan toiveet ja esteet. Perhebarometri. Väestöntutkimuslaitoksen Katsauksia E34, Helsinki: Väestöliitto.

Miller, W. \& Thoresen, C. (2003). Spirituality, religion, and health. American Psychologist, 58(1), 24-35.

Moreno Mínguez, A. (2012). Gender, family and care provision in developing countries: Towards gender equality. Progress in Development Studies 12(4), 275-300.

Mulinari, D., Keskinen, S., Irni, S. \& Tuori, S. (2009). Introduction: postcolonialism and the Nordic Models of Welfare and Gender. In: S. Keskinen, S. Tuori, S. Irni \& D. Mulinari, (eds.) Complying with colonialism. Gender, race and ethnicity in the Nordic region, pp. 1-16. Farnham: Ashgate.

Noddings, N. (2003). Happiness and education. Cambridge. Cambridge University Press.

Nätkin, R. (1997). Kamppailu suomalaisesta äitiydestä: maternalismi, väestöpolitiikka ja naisten kertomukset [The struggle over Finnish motherhood: Maternalism, population politics and women's stories]. Tampere, Finland: Gaudeamus.

Ochocka, J. \& Janzen, R. (2008). Immigrant parenting: a new framework of understanding. Journal of Immigrant \& Refugee Studies, 6(1), 85-111.

Paananen, S. (1999). Suomalaisuuden armoilla. Ulkomaalaisten työnhakijoiden luokittelu. tilastokeskus, tilastokeskuksen tutkimuksia 228. 152pp.

Pedersen, D. (2012). The good mother, the good father, and the good parent: gendered definitions of parenting. Journal of Feminist Family Therapy, 24, 230-246,

Pel, T. (2000). Muslim families from Morocco in Netherlands: Gender dynamics and fathers' roles in a context of change. Current Sociology, 48(4), 75-93.

Perälä-Littunen, S. (2004). Cultural images of a good mother and a good father in three generations. Unpublished doctoral dissertation, University of Jyväskylä, Finland.

Perälä-Littunen, S. (2007). Gender Equality or Primacy of the Mother? Ambivalent Descriptions of Good Parents. Journal of Marriage and Family, 69(2), 341-351.

Petts, R. (2009). Family and religious characteristics' influence on delinquency trajectories from adolescence to young adulthood. American Sociological Review, 74(3), 465-483. 
Phoenix, A., \& Woollett, A. (1991). Motherhood: social construction, politics and psychology. In A. Phoenix, A. Woollett, \& E. Lloyd (eds.), Motherhood: meanings, practices and ideologies, pp. 13-27. London: Sage.

Pierson, C. (1999). Beyond the welfare state. The new political economy of welfare $\left(2^{\text {nd }}\right.$ edn). Cambridge: Polity Press.

Pine, B. \& Drachman, D. (2005). Effective child welfare practice with immigrant and refugee children and their families. Child Welfare, 84(5), 537-562.

Puuronen, V. (2011). Rasistinen Suomi. [Racist Finland]. Helsinki: Gaudeamus.

Rastas, A. (2009). Rasismin Kiistäminen suomalaisessa maahanmuuttokeskustelussa. [The denial of racism in Finnish public discourses on immigration]. In: En ole rasisti, mutta... Maahanmuutosta, monikultuurisuudesta ja kritiikistä [I am not a racist but... About multiculturalism and critique]. 47-64. Tampere: Tampere: Vastapaino.

Rauhut, D. (2012). Ageing and economic performance: dilemmas and dichotomies. Finnish Yearbook of Population Research XLVII 2012, pp. 89-112.

Regushevskaya, E., Hemminki, E., Klemetti, R., Rotkirch, A., Karro, H., HaavioMannila, E. \& Miettinen, A. (2013). Postponing births - comparing reasons among women in St Petersburg, Estonia and Finland. Finnish Yearbook of Population Research XLVIII 2013, pp. 127-145.

Risman, B. (1998). Gender vertigo. American families in transition. New Haven: Yale University Press.

2004. Gender as a social structure: Theory wrestling with activism. Gender and Society, 18(4), 429-50.

Salmenhaara, P. (2008). From horizontal to vertical divides: immigrants' employment in Finland in the 1990s. Finnish Journal of Ethnicity and Migration, 3(1), 1-12.

Schippers, M. (2007). Recovering the feminine other: Masculinity, femininity, and gender hegemony. Theory and Society, 36(1), 85-102.

Schleutker, E. (2014). Fertility, family policy and welfare regimes. Comparative Population Studies, 3(1), 123-156.

Shields, M. \& Berhman, R. (2004). Children of immigrant families: analysis and recommendations, The Future of Children, 14(2), 4-15.

Shwalb, B. Shwalb \& M. Lamb (eds.) (2013). Fathers in cultural context. New York: Routledge.

Skinner, E., Johnson, S. \& Snyder, T. (2005). Six dimensions of parenting: a motivational model. Parenting: Science \& Practice, 5(2), 175-235.

Sobotka, T. (2009). Sub-replacement fertility intentions in Austria. European Journal of Population, 25(4), 387-412.

Sommestad, L. (2002). “Ålderstransitionen: Ett befolkningsperspektiv på ekonomisk och social utveckling”, i Malmberg och Sommestad (red.) Befolkning och välfärd. Stockholm: Institutet för framtidsstudier och LO.

Statistics Finland (2010). Population structure and vital statistics by municipality 2008. Population. Helsinki: Statistics Finland. www.tilastokeskus.fi/tup/suoluk/ suoluk_vaesto_en.html (2013). African Families in Finland. Statistics Received 12/06/14.

Strauss, A., \& Corbin, J. (1998). Basics of qualitative research: Techniques and 
procedures for developing grounded theory $\left(2^{\text {nd }} e d n\right.$. $)$ Thousand Oakes, CA: Sage. Sundar, P., \& Ochocka, J. (2005). Bridging the gap between dreams and realities: Employment and mental health; Implications for policy and practices. Canadian Journal of Community Mental Health, 23(1), 75-89.

Traversa, R. (2012). Religion made me free: Cultural construction of female religiosity. Culture and Psychology, 18(1), 34-59.

United Nations Development Programme [UNDP] (2007). Human Development Report 2007/2008. Oxford University Press, http://hdr.undp.org/en/reports/global/ hdr2007-2008/

Valtonen, K. (2001). Social Work with Immigrant and Refugees: Developing a Participant-based Framework for Anti-Oppression Practice. British Journal of social work, 31(6), 955-960.

Vuori, J (2001). Äidit, isät ja ammattilaiset [Mothers, fathers and professionals]. Tampere: Tampere University Press.

Woollett, A. \& Phoenix, A. (1991). Psychological views of mothering. In A. Phoenix, A. Woollett, \& E. Lloyd (eds.), Motherhood, meanings, practices and ideologies, pp. 28-46. London, UK: Sage. 